\title{
Effect of different biochars on acid soil and growth parameters of rice plants under aluminium toxicity
}

\author{
Rajpal Shetty ${ }^{1,2 \otimes}$ \& Nagabovanalli Basavarajappa Prakash ${ }^{1}$
}

Biochar is known to decrease the soil acidity and in turn enhance the plant growth by increasing soil fertility. Major objective of the present work was to understand the effect of biochar treatment on alleviation of soil aluminium (Al) toxicity and its role in enhancing plant growth parameters. Soil incubation study was conducted to understand the effect of biochar (Eucalyptus wood, bamboo, and rice husk) on soil $\mathrm{pH}$, soluble and exchangeable $\mathrm{Al}$ in soil with and without $\mathrm{Al}$ addition. Another independent pot experiment with rice crop (Oryza sativa L. var. Anagha) was carried out for 120 days to examine the effect of biochars on soil properties and growth parameters of rice plants. Wood biochar application to soil at $20 \mathrm{tha}^{-1}$ was found to be highly consistent in decreasing soil acidity and reducing soluble and exchangeable Al under both studies. We conclude that wood biochar at higher dose performed better in reducing soluble and exchangeable $\mathrm{Al}$ in comparison to other biochars indicating its higher ameliorating capacity. However, rice husk biochar was effective under Al untreated soil, indicating the role of Si-rich biochars in enhancing plant growth.

Soil acidity in many parts of the world poses a significant challenge to crop productivity. Around $30 \%$ of the total land area in the world and more than $50 \%$ of the world's potentially arable area fall under acidic soils ${ }^{1-3}$. Approximately $30 \%$ of arable land in India are acidic in nature, resulting in low crop yield ${ }^{3}$. Acid soils have low $\mathrm{pH}$ values $(<5.5$ or 6$)$ and are usually associated with the severe aluminium (Al) toxicity to plants. Aluminium is mainly in the form of insoluble silicate or oxide in neutral soils $(\mathrm{pH}=6.5-7.5)$. However, low soil $\mathrm{pH}(<5)$ leads to the solubilization of $\mathrm{Al}$, primarily to the phytotoxic form of $\mathrm{Al}^{3+}$ in soil solution ${ }^{4,5}$.

Aluminium toxicity has been reported to cause direct inhibition of root elongation and further interfere with uptake of plant nutrients ${ }^{6,7}$. Aluminium toxicity can therefore be considered a primary limiting factor in acid soils for plant growth and development. Consequently, focusing on worldwide acid soil remediation is crucial to enhance crop yield and thus alleviating world hunger. Liming has been the prominent approach for amending acid soil. However, biochar application as soil amendment has been receiving lot of attention, for many reasons such as neutralizing acidity in soil, creating a carbon (C) sink to mitigate global warming, increasing soil water holding capacity, reducing greenhouse gas emissions and stabilizing mobile heavy metals, pesticides and other organic pollutants in soil ${ }^{8-12}$.

Biochar is carbon rich material obtained by pyrolysis of biomass with little or no oxygen ${ }^{13}$. Pyrolysis of plant biomass normally results highly alkaline biochar ${ }^{13-15}$. However, alkalinity varies with respect to feedstock properties used for the biochar production. Greater the alkalinity of biochar, greater is the reduction in acidity ${ }^{16}$. Addition of biochar to nutrient poor soil has been reported to enhance nutrient availability and increase plant biomass ${ }^{17}$. Application of peanut shell biochar to highly acidic red soil was reported to enhance growth in cabbage by reducing $\mathrm{Al}$ toxicity owing to increased soil $\mathrm{pH}$ and nutrient availability ${ }^{18}$. High surface charge density, large surface area and internal porosity, and presence of both polar and non-polar surface sites on biochar play a vital role in metal adsorption along with the liming effect ${ }^{14}$. Therefore, incorporation of biochar into acid soil could help to mitigate soil Al toxicity by decreasing soil exchangeable acidity, increasing soil exchangeable base cations, and thereby improving soil fertility. A lot of studies have been carried out on the impact of biochar on soil acidity $^{19-21}$. However, very few studies have specifically focussed on the impact of biochar on soil Al content ${ }^{18,22}$.

The purpose of this study was to evaluate the impact of different biochar sources and rates on the extent of Al toxicity mitigation in acid soil under incubated condition. Additionally, an independent pot experiment was

${ }^{1}$ Department of Soil Science and Agricultural Chemistry, University of Agricultural Sciences, GKVK, Bengaluru, India. 'Department of Plant Physiology, Faculty of Natural Sciences, Comenius University, Bratislava, Slovakia. ${ }^{\circledR}$ email: rskpur007@gmail.com 


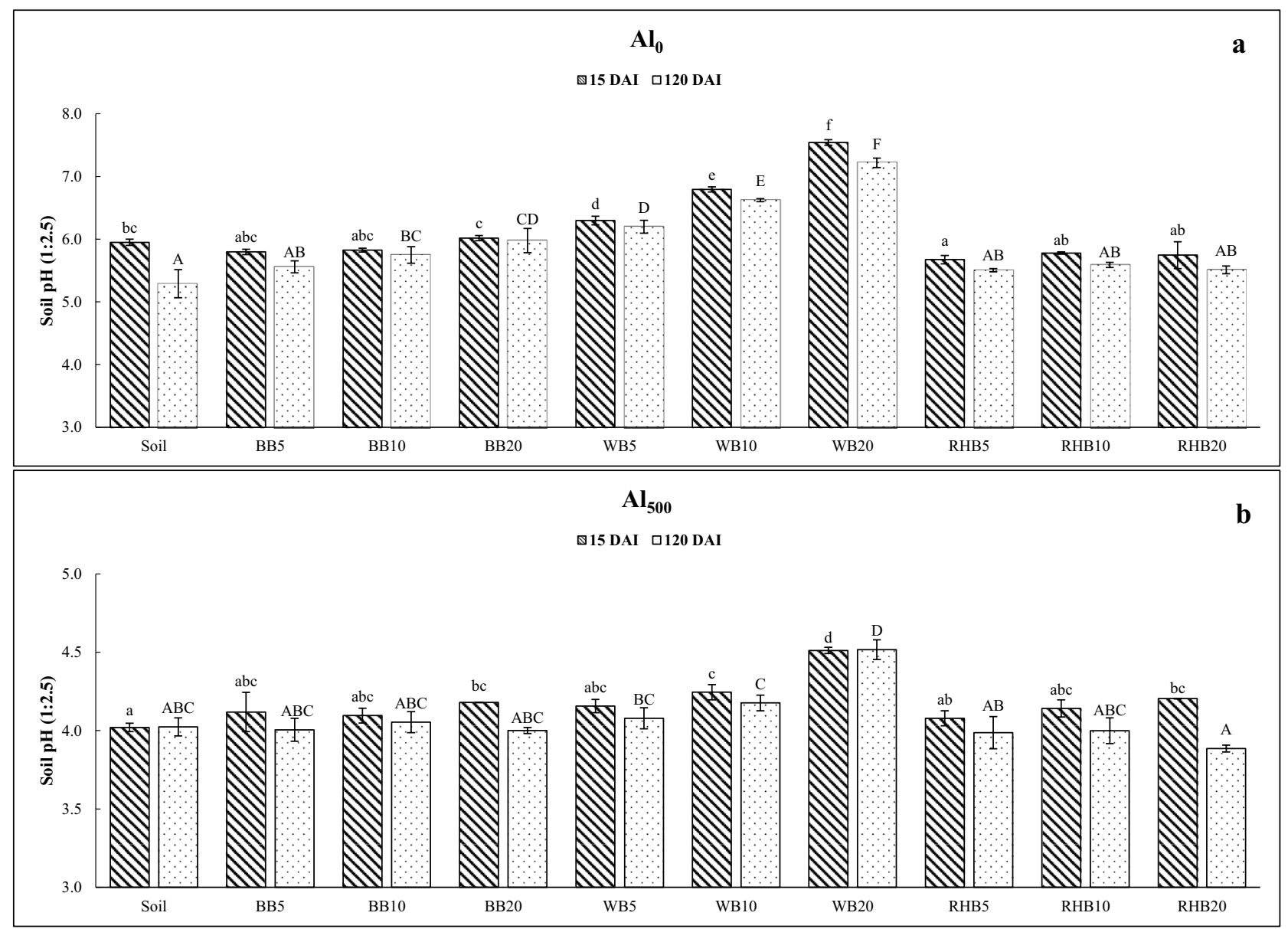

Figure 1. Incubation study: effect of different biochar treatments on soil $\mathrm{pH}$. (a) Changes in soil $\mathrm{pH}$ in $\mathrm{Al}$ untreated soil $\left(\mathrm{Al}_{0}: 0 \mathrm{mg} \mathrm{kg}{ }^{-1}\right)$ and $(\mathbf{b})$ changes in soil $\mathrm{pH}$ in $\mathrm{Al}$ treated soil $\left(\mathrm{Al}_{500}: 500 \mathrm{mg} \mathrm{kg}^{-1}\right)$. BB: bamboo biochar. WB: wood biochar. RHB: rice husk biochar. DAI: days after incubation. Biochar rates in $\mathrm{t} \mathrm{ha}^{-1}$. Each value represents the mean of three replicates \pm standard error. Mean values marked with same letters do not differ significantly according to the Tukey's HSD test at $p \leq 0.05$.

performed to investigate the performance of different biochar sources and rates on soil properties and on certain growth parameters of rice plants under acid soils.

\section{Results}

Incubation study: effect of biochar on soil $\mathrm{pH}$, soluble and exchangeable Al. Soil without Al treatment. Addition of wood biochar (WB) at all application rates $\left(5,10\right.$ and $\left.20 \mathrm{t} \mathrm{ha}^{-1}\right)$ led to a significant increase in soil $\mathrm{pH}$ at 15 days after incubation (DAI) (Fig. 1a). The addition of WB at all application rates, and the application of bamboo biochar (BB) at the rates of 10 and $20 \mathrm{t} \mathrm{ha}^{-1}$ led to an increase in soil pH after 120 days. However, application of rice husk biochar (RHB) did not increase the soil $\mathrm{pH}$. Soluble and exchangeable Al were not detected under $\mathrm{Al}$ untreated soil.

Soil with $500 \mathrm{mg} \mathrm{kg}^{-1}$ Al treatment. Addition of WB at 10 and $20 \mathrm{t} \mathrm{ha}^{-1}, \mathrm{BB}$ and RHB at $20 \mathrm{tha}^{-1}$ significantly increased the soil pH compared to control at 15 DAI (Fig. 1b). Nonetheless, after 120 DAI only WB at 20 t ha $^{-1}$ was found to significantly increase the soil $\mathrm{pH}$ compared to control.

The addition of WB at all application rates, BB at the rate of $20 \mathrm{t} \mathrm{ha}^{-1}$, and RHB at the rates of 10 and $20 \mathrm{tha}^{-1}$ significantly decreased the soluble $\mathrm{Al}$ in soil at $15 \mathrm{DAI}$ (Fig. 2a). Similar effect was noticed after $120 \mathrm{DAI}$ except for $\mathrm{BB}$ and $\mathrm{RHB}$ at the rate of $5 \mathrm{tha}^{-1}$.

The addition of WB at all application rates, and RHB at $20 \mathrm{tha}^{-1}$ significantly decreased the exchangeable $\mathrm{Al}$ at $15 \mathrm{DAI}$ compared to soil without biochar treatment (Fig. 2b). However, only WB and BB at the rate of 20 $\mathrm{t} \mathrm{ha}^{-1}$ significantly decreased the exchangeable $\mathrm{Al}$ at 120 DAI.

Pot study with rice crop: effect of biochar on soil properties after harvest. Soil without Al treatment. Addition of WB at all application rates $\left(10\right.$ and $\left.20 \mathrm{t} \mathrm{ha}^{-1}\right)$, and the application of $\mathrm{BB}$ at the rate of $20 \mathrm{t}$ $\mathrm{ha}^{-1}$ led to significant increase in the soil pH (Fig. 3a). Soil electrical conductivity (EC) was increased with the application of WB at $20 \mathrm{t} \mathrm{ha}^{-1}$ compared to other treatments (Table 1). Biochar treatments did not impact soil 


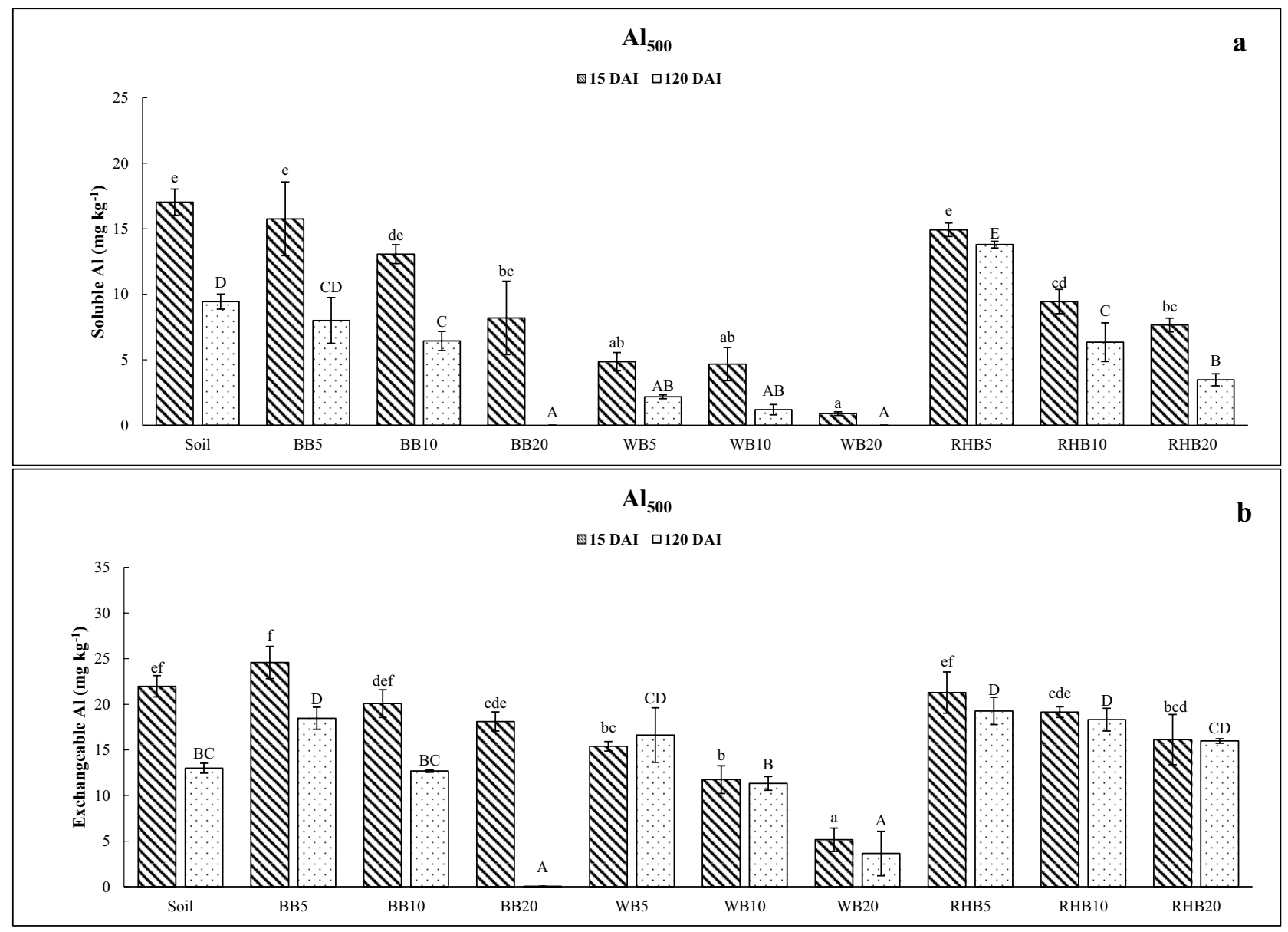

Figure 2. Incubation study: effect of different biochar treatments on the soluble and exchangeable $\mathrm{Al}$ content of soil. (a) Changes in soluble $\mathrm{Al}$ in $\mathrm{Al}$ treated soil $\left(\mathrm{Al}_{500}: 500 \mathrm{mg} \mathrm{kg}^{-1}\right)$ and (b) changes in exchangeable $\mathrm{Al}$ under $\mathrm{Al}$ treated soil $\left(\mathrm{Al}_{500}: 500 \mathrm{mg} \mathrm{kg}{ }^{-1}\right)$. BB: bamboo biochar. WB: wood biochar. RHB: rice husk biochar. DAI: days after incubation. Biochar rates in $\mathrm{t} \mathrm{ha}^{-1}$. Each value represents the mean of three replicates \pm standard error. Mean values marked with same letters do not differ significantly according to the Tukey's HSD test at $p \leq 0.05$.

exchangeable acidity or exchangeable calcium (Ca). Interestingly, addition of biochars at all application rates increased the available silicon $(\mathrm{Si})$ in soil, wherein significant increase to an extent of $119.21 \mathrm{mg} \mathrm{kg}^{-1} \mathrm{Si}_{\text {was }}$ found due to the addition of RHB at the rate of $20 \mathrm{t} \mathrm{ha}^{-1}$. However, there was no detectable quantities of soluble or exchangeable $\mathrm{Al}$ in soil, either due to the biochar addition or in control soil.

Soil with $500 \mathrm{mg} \mathrm{kg}^{-1} \mathrm{Al}$ treatment. Soil $\mathrm{pH}$ in Al treated soil significantly increased by addition of WB at all application rates, and the application of BB at the rate of $20 \mathrm{t} \mathrm{ha}^{-1}$ (Fig. 3b). Increasing trend of soil EC was noticed by all the rates of biochar application. The highest increase in soil EC was observed with addition of WB at the rate of $20 \mathrm{tha}^{-1}$ compared to soil without biochar treatment (Table 1). Addition of biochar at all the rates decreased the soil exchangeable acidity, although highest reduction was noticed by the addition of WB at the rate of $20 \mathrm{t} \mathrm{ha}^{-1}$. Similarly, addition of WB at the rate of $20 \mathrm{tha}^{-1}$ significantly increased the exchangeable Ca in soil compared to other treatments. However, soil Si content was higher with addition of RHB at the rate of $20 \mathrm{t}$ $\mathrm{ha}^{-1}$. Addition of $\mathrm{WB}$ at all application rates significantly reduced the soluble and exchangeable $\mathrm{Al}$ compared to all the treatments (Fig. 3c, d).

Pot study with rice crop: effect of biochar on the growth parameters of rice crop. Soil without Al treatment. Application of RHB at the rate of 10 and $20 \mathrm{t} \mathrm{ha}^{-1}$ significantly increased the plant height, shoot and root dry weight compared to all the treatments (Table 2). However, biochar addition did not produce any significant effect on root length of rice crop grown in $\mathrm{Al}$ untreated soil.

Soil with $500 \mathrm{mg} \mathrm{kg}^{-1} \mathrm{Al}$ treatment. Aluminium addition to the soil decreased all the plant growth parameters measured (plant height, shoot and root dry weight, and root length) compared to plants grown in soil without $\mathrm{Al}$ addition. However, biochar treatments aided in improvement of those parameters. Plant height was significantly improved by the addition of RHB at the rate of $20 \mathrm{tha}^{-1}$. Addition of WB and RHB at the rate of $20 \mathrm{tha}^{-1}$ significantly increased the shoot dry weight. There was no significant change in root dry weight, even though 

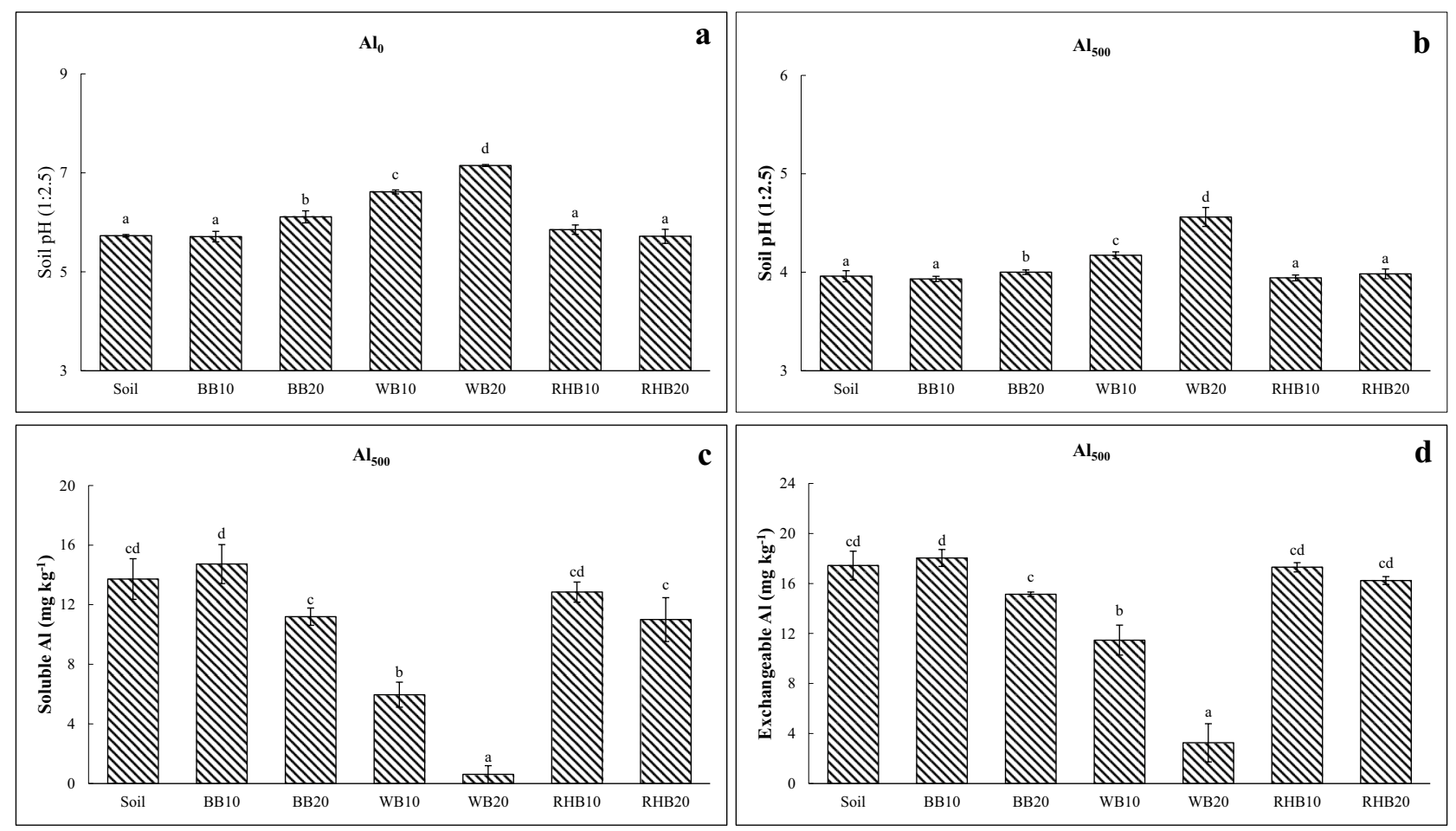

Figure 3. Pot study with rice crop: effect of different biochar treatments on the soil $\mathrm{pH}$, soluble and exchangeable $\mathrm{Al}$ content of soil. (a) Changes in soil $\mathrm{pH}$ in $\mathrm{Al}$ untreated soil $\left(\mathrm{Al}_{0}: 0 \mathrm{mg} \mathrm{kg}{ }^{-1}\right)$, (b) changes in soil $\mathrm{pH}$ in $\mathrm{Al}$ treated soil $\left(\mathrm{Al}_{500}: 500 \mathrm{mg} \mathrm{kg}{ }^{-1}\right)$, (c) changes in soluble $\mathrm{Al}$ in $\mathrm{Al}$ treated soil $\left(\mathrm{Al}_{500}: 500 \mathrm{mg} \mathrm{kg}{ }^{-1}\right)$ and (d) changes in exchangeable $\mathrm{Al}$ in $\mathrm{Al}$ treated soil $\left(\mathrm{Al}_{500}: 500 \mathrm{mg} \mathrm{kg}{ }^{-1}\right.$ ). BB: bamboo biochar. WB: wood biochar. RHB: rice husk biochar. Biochar rates in $\mathrm{tha}^{-1}$. Each value represents the mean of three replicates \pm standard error. Mean values marked with same letters do not differ significantly according to the Tukey's HSD test at $p \leq 0.05$.

\begin{tabular}{|c|c|c|c|c|c|c|c|c|}
\hline \multirow[b]{2}{*}{ Treatments } & \multicolumn{2}{|l|}{$\mathrm{EC}\left(\mathrm{dS} \mathbf{~ m}^{-1}\right)$} & \multicolumn{2}{|c|}{$\begin{array}{l}\text { Exchangeable acidity }(\mathrm{cmol}(\mathrm{p}+) \\
\left.\mathrm{kg}^{-1}\right)\end{array}$} & \multicolumn{2}{|c|}{ Exchangeable Ca $\left(\mathrm{cmol}(\mathrm{p}+) \mathrm{kg}^{-1}\right)$} & \multicolumn{2}{|c|}{ Available Si $\left(\mathrm{mg} \mathrm{kg}^{-1}\right)$} \\
\hline & $\mathrm{Al}_{0}$ & $\mathrm{Al}_{500}$ & $\mathrm{Al}_{0}$ & $\mathrm{Al}_{500}$ & $\mathrm{Al}_{0}$ & $\mathrm{Al}_{500}$ & $\mathrm{Al}_{0}$ & $\mathrm{Al}_{500}$ \\
\hline Soil & $0.45 \pm 0.01(\mathrm{ab})$ & $0.95 \pm 0.22(a)$ & $0.20 \pm 0.05$ (a) & $3.16 \pm 0.31(\mathrm{~d})$ & $2.28 \pm 0.09$ (a) & $1.90 \pm 0.27$ (a) & $63.00 \pm 4.95(\mathrm{a})$ & $44.92 \pm 4.16(\mathrm{ab})$ \\
\hline BB $10 \mathrm{tha}^{-1}$ & $0.32 \pm 0.14(\mathrm{a})$ & $1.05 \pm 0.10(\mathrm{ab})$ & $0.18 \pm 0.06(\mathrm{a})$ & $2.80 \pm 0.13(\mathrm{~cd})$ & $2.68 \pm 0.60(a)$ & $2.54 \pm 0.46(\mathrm{ab})$ & $70.42 \pm 8.94(\mathrm{ab})$ & $47.00 \pm 9.99(\mathrm{ab})$ \\
\hline BB $20 \mathrm{t} \mathrm{ha}^{-1}$ & $0.33 \pm 0.05(\mathrm{a})$ & $1.52 \pm 0.16(\mathrm{bc})$ & $0.27 \pm 0.16(\mathrm{a})$ & $2.90 \pm 0.28(\mathrm{~cd})$ & $1.93 \pm 0.24(\mathrm{a})$ & $3.03 \pm 0.06(\mathrm{bc})$ & $88.17 \pm 18.51(b c)$ & $36.71 \pm 0.15(\mathrm{a})$ \\
\hline WB 10 t ha $^{-1}$ & $0.42 \pm 0.04(\mathrm{ab})$ & $1.57 \pm 0.09(\mathrm{c})$ & $0.10 \pm 0.00(\mathrm{a})$ & $1.88 \pm 0.20(\mathrm{~b})$ & $1.69 \pm 0.59$ (a) & $4.14 \pm 0.18(\mathrm{~d})$ & $83.46 \pm 4.98(\mathrm{abc})$ & $39.46 \pm 3.29(\mathrm{ab})$ \\
\hline WB $20 \mathrm{t} \mathrm{ha}^{-1}$ & $0.52 \pm 0.01(b)$ & $1.60 \pm 0.15(\mathrm{c})$ & $0.12 \pm 0.03$ (a) & $0.96 \pm 0.08$ (a) & $3.02 \pm 1.75$ (a) & $5.16 \pm 0.21(\mathrm{e})$ & $95.17 \pm 4.90(\mathrm{~cd})$ & $46.38 \pm 4.59(\mathrm{ab})$ \\
\hline RHB $10 \mathrm{t} \mathrm{ha}^{-1}$ & $0.34 \pm 0.06(a)$ & $1.55 \pm 0.27(\mathrm{c})$ & $0.15 \pm 0.00$ (a) & $2.58 \pm 0.08(\mathrm{c})$ & $2.29 \pm 0.06(\mathrm{a})$ & $3.60 \pm 0.56(\mathrm{~cd})$ & $93.04 \pm 1.38(\mathrm{bc})$ & $46.75 \pm 4.25(\mathrm{ab})$ \\
\hline RHB $20 \mathrm{t} \mathrm{ha}^{-1}$ & $0.38 \pm 0.03(\mathrm{ab})$ & $1.55 \pm 0.15(\mathrm{c})$ & $0.15 \pm 0.00$ (a) & $2.93 \pm 0.06(\mathrm{~cd})$ & $2.30 \pm 0.08$ (a) & $3.56 \pm 0.08(\mathrm{~cd})$ & $119.21 \pm 4.85(\mathrm{~d})$ & $51.96 \pm 2.47(\mathrm{~b})$ \\
\hline
\end{tabular}

Table 1. Pot study with rice crop: effect of different biochar treatments on the selected soil properties under $\mathrm{Al}$ untreated $\left(\mathrm{Al}_{0}: 0 \mathrm{mg} \mathrm{kg}^{-1}\right)$ and $\mathrm{Al}$ treated soil $\left(\mathrm{Al}_{500}: 500 \mathrm{mg} \mathrm{kg}^{-1}\right)$. BB: bamboo biochar, WB: wood biochar, RHB: rice husk biochar. Each value represents the mean of three replicates \pm standard error. Mean values marked with same letters do not differ significantly according to the Tukey's HSD test at $p \leq 0.05$.

biochar treatments increased root dry weight compared to soil without biochar treatment. However, biochar treatments increased the root length, wherein significant increase was noticed by the application of WB at the rate of $20 \mathrm{tha}^{-1}$.

\section{Discussion}

Soil pH. Application of WB increased the soil $\mathrm{pH}$ in both $\mathrm{Al}$ treated and untreated soils. Many studies have reported substantial increase in soil $\mathrm{pH}$ by the biochar treatment ${ }^{15,17,20,21,23,24}$. This has been attributed to the liming potential of biochar due to high inherent $\mathrm{pH}$ of biochar, base cation content, $\mathrm{CaCO}_{3}$ content and calcium carbonate equivalent $(\mathrm{CCE})^{20,21}$. Increase in $\mathrm{pH}$ with the application of WB is due to high $\mathrm{pH}$ of WB and high EC indicating its higher soluble salts, greater CCE and Ca content compared to other biochars ${ }^{12,13,17}$. Biochar application might have resulted in neutralization of soil acidity by series of proton consumption reactions as reported 


\begin{tabular}{|c|c|c|c|c|c|c|c|c|}
\hline \multirow[b]{2}{*}{ Treatments } & \multicolumn{2}{|l|}{ Plant height $(\mathrm{cm})$} & \multicolumn{2}{|c|}{ Shoot dry weight (g) } & \multicolumn{2}{|c|}{ Root dry weight (g) } & \multicolumn{2}{|c|}{ Root length $(\mathrm{cm})$} \\
\hline & $\mathbf{A l}_{0}$ & $\mathrm{Al}_{500}$ & $\mathbf{A l}_{0}$ & $\mathrm{Al}_{500}$ & $\mathbf{A l}_{0}$ & $\mathrm{Al}_{500}$ & $\mathrm{Al}_{\mathbf{0}}$ & $\mathrm{Al}_{500}$ \\
\hline Soil & $87.50 \pm 2.29(\mathrm{ab})$ & $71.03 \pm 1.30$ (a) & $5.55 \pm 0.36$ (a) & $2.88 \pm 0.51$ (a) & $0.93 \pm 0.06(\mathrm{ab})$ & $0.63 \pm 0.09$ (a) & $27.66 \pm 2.52$ (a) & $13.67 \pm 0.58$ (a) \\
\hline BB $10 \mathrm{tha}^{-1}$ & $85.23 \pm 2.47$ (a) & $74.50 \pm 2.78(\mathrm{ab})$ & $5.38 \pm 0.13$ (a) & $3.30 \pm 0.74(\mathrm{ab})$ & $0.91 \pm 0.04(\mathrm{ab})$ & $0.71 \pm 0.06$ (a) & $33.00 \pm 3.61$ (a) & $15.00 \pm 3.00(\mathrm{ab})$ \\
\hline BB $20 \mathrm{t} \mathrm{ha}^{-1}$ & $87.87 \pm 2.23(\mathrm{abc})$ & $78.15 \pm 6.53(\mathrm{ab})$ & $5.53 \pm 0.86$ (a) & $4.51 \pm 1.12(\mathrm{ab})$ & $1.09 \pm 0.17(\mathrm{abc})$ & $0.77 \pm 0.24$ (a) & $34.33 \pm 9.29$ (a) & $16.00 \pm 6.00(\mathrm{ab})$ \\
\hline WB $10 \mathrm{tha}^{-1}$ & $87.86 \pm 2.73(\mathrm{abc})$ & $80.58 \pm 8.34(\mathrm{ab})$ & $5.44 \pm 0.02$ (a) & $4.88 \pm 0.97(\mathrm{ab})$ & $0.88 \pm 0.12$ (a) & $0.88 \pm 0.08$ (a) & $30.67 \pm 5.13$ (a) & $19.67 \pm 0.58(\mathrm{ab})$ \\
\hline WB $20 \mathrm{t} \mathrm{ha}^{-1}$ & $92.10 \pm 3.20(\mathrm{abc})$ & $79.52 \pm 5.41(\mathrm{ab})$ & $5.72 \pm 0.22$ (a) & $5.40 \pm 0.15$ (b) & $0.98 \pm 0.10(\mathrm{ab})$ & $0.89 \pm 0.21$ (a) & $32.33 \pm 3.21$ (a) & $22.00 \pm 2.65$ (b) \\
\hline RHB $10 \mathrm{t} \mathrm{ha}^{-1}$ & $96.47 \pm 3.86(\mathrm{c})$ & $79.78 \pm 6.33(\mathrm{ab})$ & $8.48 \pm 0.97$ (b) & $3.59 \pm 0.33(\mathrm{ab})$ & $1.26 \pm 0.26$ (bc) & $0.65 \pm 0.26$ (a) & $25.33 \pm 0.58$ (a) & $18.00 \pm 2.00(\mathrm{ab})$ \\
\hline RHB $20 \mathrm{t} \mathrm{ha}^{-1}$ & $95.55 \pm 4.72(\mathrm{bc})$ & $88.32 \pm 7.02(\mathrm{~b})$ & $9.25 \pm 0.83(\mathrm{~b})$ & $5.42 \pm 1.51(\mathrm{~b})$ & $1.46 \pm 0.08(\mathrm{c})$ & $0.68 \pm 0.14(\mathrm{a})$ & $27.67 \pm 2.52(\mathrm{a})$ & $19.33 \pm 2.31(\mathrm{ab})$ \\
\hline
\end{tabular}

Table 2. Pot study with rice crop: effect of different biochar treatments on the measured plant growth parameters under $\mathrm{Al}$ untreated $\left(\mathrm{Al}_{0}: 0 \mathrm{mg} \mathrm{kg}{ }^{-1}\right)$ and $\mathrm{Al}$ treated soil $\left(\mathrm{Al}_{500}: 500 \mathrm{mg} \mathrm{kg}^{-1}\right)$. BB: bamboo biochar, WB: wood biochar, RHB: rice husk biochar. Each value represents the mean of three replicates \pm standard error. Mean values marked with same letters do not differ significantly according to the Tukey's HSD test at $p \leq 0.05$.

by many studies ${ }^{15,21}$. However, consistent reduction in soil acidity by BB was only at $20 \mathrm{tha}^{-1}$, both in incubation and pot study with rice plants. Even, $\mathrm{RHB}$ was inconsistent in decreasing the soil $\mathrm{pH}$, and in some cases, $\mathrm{pH}$ was lower than control. This can be due to lower production temperature, lower $\mathrm{pH}$, and $\mathrm{EC}$ of $\mathrm{RHB}^{25}$. This shows that the $\mathrm{pH}$ of biochar is not the only parameter decreasing the soil acidity. Different biomass feedstocks and pyrolytic conditions mainly influences biochar properties. For example, biochar produced from leguminous feedstock can have higher liming potential than non-leguminous feedstocks ${ }^{15,16}$. In the present investigation, feedstocks from wood, bamboo and rice husk had varied properties. We assume that higher liming potential of wood biochar might be due to high uptake of basic cations from the Eucalyptus trees. Moreover, RHB had high content of $\mathrm{N}$ which might have aggravated the soil nitrification contributing to the acidity. McBeath and Smernik $^{26}$ reported faster mineralization and degradability of biochar produced at lower temperature. Similarly, Harris et al. ${ }^{27}$ observed higher mineralization of $\mathrm{C}$ in case of peanut hull biochar than pine chip biochar as it contains three times higher ash and approximately $12 \mathrm{~g} \mathrm{~kg}^{-1}$ more aliphatic compounds than pine chip biochar. Similarly, Yuan et al. ${ }^{16}$ in an incubation study demonstrated that an increase in soil $\mathrm{pH}$ with application of different crop residue was inversely proportional to their nitrogen $(\mathrm{N})$ content. Therefore, possible mineralization and subsequent nitrification of RHB might be the reason for reduction in the soil $\mathrm{pH}$ in our study. Interestingly, all the $\mathrm{pH}$ values in the present investigation had a decreasing trend at the end of incubation. This might be due to decomposition of soil organic matter and other microbial processes such as nitrification contributing to the soil acidity. Such decrease in $\mathrm{pH}$ with incubation time was also noticed by Hass et al. ${ }^{28}$ and Wan et al..$^{29}$. However, from the pot study with rice plants having higher soil quantity compared to incubation, it was clearly noticed that $\mathrm{WB}$ application rates consistently decreased $\mathrm{pH}$ both under $\mathrm{Al}$ treated and untreated soils compared to other biochar treatments.

Soluble and exchangeable Al. Recent studies indicate that liming effect of biochar, adsorption properties and the surface adsorption and co-precipitation of Al with silicate particles to fix $\mathrm{Al}$ in soil ${ }^{22,30,31}$. Similarly, biochar application to Al treated soil in our study reduced the soluble and exchangeable Al. These results are consistent with several reports suggesting that biochar application has potential to decrease Al toxicity in soil ${ }^{22,30,32}$. Increase in biochar rates can multiply its liming effect leading to strong adsorption of $\mathrm{Al}$ monomers and further conversion of toxic $\mathrm{Al}^{3+}$ to less toxic $\mathrm{Al}(\mathrm{OH})_{3}$ and $\mathrm{Al}(\mathrm{OH})_{4}{ }^{-}$species $^{22}$.

Addition of WB and increase in its rate of application to Al treated soil significantly decreased the soluble and exchangeable $\mathrm{Al}$ at the end of the incubation period (Fig. 2). Dang et al. ${ }^{33}$ reported that Eucalyptus biochar prepared at $550^{\circ} \mathrm{C}$ had high proton, $\mathrm{Al}$, and iron $(\mathrm{Fe})$ binding capacity due to various kinds of functional groups. Additionally, larger porosity of WB used in our study indicates higher surface area which in turn might have improved adsorption capacity ${ }^{25}$. Qian et al. ${ }^{22}$ reported that the biochar's adsorption and precipitation capacity plays greater role in $\mathrm{Al}$ toxicity alleviation compared to its alkalinity. Complexation of $\mathrm{Al}$ with organic hydroxyl and carboxyl groups or the surface adsorption and co-precipitation of Al with silicate particles in biochar are reported as effective mechanisms.

There was no significant reduction in soluble and exchangeable $\mathrm{Al}$ of soil by treating $\mathrm{BB}$ or RHB with the application of less than $10 \mathrm{tha}^{-1}$ at the end of both studies. Sometimes, the soluble and exchangeable $\mathrm{Al}$ was noticed to be higher than control. We suppose that the substantial decrease in soil $\mathrm{pH}$ led to release of inherent $\mathrm{Al}$ of $\mathrm{BB}$ and $\mathrm{RHB}$ and thus increased the availability of $\mathrm{Al}$ in soil. Bamboo biochar did not have the same effect as WB even though it had properties like high $\mathrm{pH}$ and Si content. Similarly, RHB did not prove to be as effective as WB even with highest Si content and nearly equal CCE. This suggests that the alleviation of Al toxicity by biochar depends on its feed stock materials, pyrolysis temperature and other properties which play interdependent role.

Soil EC. Significant increase in soil EC with biochar application has often been reported in previous studies $^{12,17,21,34,35}$. In our study, biochar application to Al untreated soil did not increase the soil EC. However, increasing trend in soil EC was noticed by biochar application under $\mathrm{Al}$ treated soil. Highest increase was in case of WB at $20 \mathrm{tha}^{-1}$ compared to control. Natural increase in soil EC due to the increase in soluble salt content brought by increase in soil $\mathrm{Al}$ might be one of the reasons. Further, basic cations present in biochar might have solubilised into the soil solution under highly acidic $\mathrm{pH}$ resulting net increase of soil EC. 
Exchangeable acidity. The reduction of exchangeable acidity of soil clearly indicates the ability of biochars to decrease the exchangeable $\mathrm{Al}^{3+}$ and $\mathrm{H}^{+}$in soil solution. The largest reduction was in case of WB at 10 and $20 \mathrm{t} \mathrm{ha}^{-1}$ and RHB at $10 \mathrm{t} \mathrm{ha}^{-1}$. Similar results were reported by Yamato et al. ${ }^{36}$, wherein wood biochar (bark of Acaia mangium) application was found to reduce the exchangeable acidity significantly under highly acidic soil.

Exchangeable Ca. Free bases present in biochar such as $\mathrm{Ca}$, magnesium $(\mathrm{Mg})$ and potassium $(\mathrm{K})$ can be readily released into to the soil solution resulting in net increase of soil pH and exchangeable bases. Such observations were also noticed by Lehmann et al. ${ }^{19}$ and Chan et al. $^{35}$. In contrast, biochar treatments in our study did not affect exchangeable Ca under Al untreated soil. However, significant increase in Ca was noticed by biochar treatments under Al treated soil. Similar trend was reported by Silber et al. ${ }^{37}$ in a study on kinetics of release of $\mathrm{Ca}$ from corn straw biochar that the $\mathrm{Ca}$ release was increased as $\mathrm{pH}$ decreased. The largest increase in the present investigation was in case of WB at $20 \mathrm{t} \mathrm{ha}^{-1}$ in both $\mathrm{Al}$ treated and untreated soil indicating its liming potential.

Available Si. Addition of biochar at all application rates increased the available Si in Al untreated soil. However, available Si content was decreased in Al treated soil. Increase in available Si might be due to increase in soil $\mathrm{pH}$ by alkaline biochar in turn enhancing Si availability and by the additional input of inherent Si from biochar ${ }^{38}$. Inversely, low $\mathrm{pH}$ by the addition of $\mathrm{Al}$ to soil might have hindered the dissolution and release of Si from biochar and further complexation of $\mathrm{Si}$ with free $\mathrm{Al}$ in soil solution. Highest increase in Si was observed by the addition of RHB at $20 \mathrm{tha}^{-1}$ under both $\mathrm{Al}$ treated and untreated soil, owing to its inherent Si content. Similar studies with rice husk and straw biochars have proven to significantly increase Si availability to plants ${ }^{30,38-40}$.

Plant growth parameters. Aluminium decreased all the plant growth parameters due to its phytotoxicity, which mainly inhibits the root elongation. Previous studies have noticed the effect of Al toxicity on plants such as inhibiting root elongation, biomass reduction, oxidative stress, disrupting the function of the plasma membrane and cell wall, disordering calcium homeostasis, altering the signal transduction pathways and DNA damage $^{7}$. However, biochar application has shown to aid in improvement of those parameters. Improvement of plant height and productive tillers per plant by biochar application has been reported previously ${ }^{11,41}$. Similarly, addition of WB and RHB in our study have shown profound influence in increasing plant height, shoot and root dry weight and further reducing the root length.

Biochar from rice husk might have had higher advantage due to its substantial amount of Si content. Beneficial effect of Si on the rice plant height and number of tillers are well known ${ }^{42-44}$. Recent studies have reported that Si rich biochars obtained by the feedstocks such as rice husk and straw have high potential in increasing soil available $\mathrm{Si}^{30,32,38,39}$. Such phytoavailable $\mathrm{Si}$ might further assist in decreasing Al toxicity to plants by forming the $\mathrm{Al}-\mathrm{Si}$ compounds in the soil solution and in root tip ${ }^{30}$. On the other hand, WB at higher dose improved root length significantly compared to soil with Al treatment alone. This might be due to increase in the soil $\mathrm{pH}$ providing favourable plant growth conditions and reducing metal toxicity by complexation and precipitation of toxic $\mathrm{Al}^{3+}$. In addition, large boron (B) content in WB might have decreased $\mathrm{Al}^{3+}$ accumulation to cell wall and thus decreasing Al phytotoxicity. Many studies have reported that the optimum supply of B in soil can enhance root elongation, decrease $\mathrm{Al}$ content in root apoplast, prevents root injury and further promotes plant growth under Al toxicity ${ }^{45-47}$.

Numerous factors can act individually or simultaneously to increase plant growth under biochar treatments; viz., decrease in soluble $\mathrm{Al}$ and $\mathrm{Fe}$, increase in soil $\mathrm{pH}$, balanced and slow release of nutrients, increased plant available water and improved microbial activity. RHB being a rich source of majority of essential nutrients promoted the plant growth, in addition to its high CEC, Si and ash content. But especially under Al treated soil, WB performed better by decreasing the Al phytotoxicity to plant roots and thus improving the plant growth attributes. Hence, our study indicates the performance of WB as Al toxicity ameliorant, whereas RHB as a potential soil nutrient supplement with special reference to $\mathrm{Si}$.

\section{Conclusions}

Application of wood biochar to amend $\mathrm{Al}$ toxicity in the present study was proved to be very effective. It had a consistent effect on increasing soil $\mathrm{pH}$ and decreasing the soluble and exchangeable Al. Thus, improved the soil nutrient availability resulting in the higher yield of experimental plants. On the other hand, application of rice husk biochar enhanced the plant growth most significantly in Al untreated soil, even though it did not match the performance of wood biochar with respect to Al reduction in Al treated soil. Possible reason for higher yield with application of rice husk biochar may be due to higher availability of nutrients and especially benefits of $\mathrm{Si}$ on rice crop. However, low performance of $\mathrm{RHB}$ in $\mathrm{Al}$ treated soil due to its low $\mathrm{pH}, \mathrm{EC}, \mathrm{Ca}$, and $\mathrm{B}$ content. It is evident that the ameliorating effect of biochar is dependent on its $\mathrm{pH}$ value, pyrolysis temperature and feedstock materials. Hence, categorization of potential biochars for amending the Al toxic soil must be recommended based on their individual properties. Long term field trials on $\mathrm{Al}$ contaminated soils must be conducted to further evaluate the effectiveness of biochar as an amendment for sustainable remediation of $\mathrm{Al}$ contaminated acidic soils.

\section{Materials and methods}

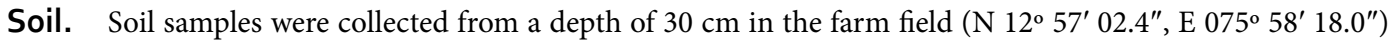
located in the Hassan district of Karnataka, South India representing southern dry zone and taxonomically classified as Rhodic Paleustalfs. Collected soil was air dried and sieved using $2 \mathrm{~mm}$ sieve. Particle size determination by international pipette method $^{48}$ revealed that the soil is of sandy loam texture consisting of $68.95 \%$ sand, $8.65 \%$ silt and $22.40 \%$ clay. Some of the initial properties of the soil are shown in Table 3. 


\begin{tabular}{|l|l|}
\hline Parameters & Mean \\
\hline $\mathrm{pH}(1: 2.5)$ & 5.96 \\
\hline $\mathrm{EC}\left(\mathrm{dSm}^{-1}\right)$ & 0.15 \\
\hline Exchangeable acidity $\left(\mathrm{m}\right.$. eq $\left.\mathrm{H}^{+} 100 \mathrm{~g}^{-1}\right)$ & 0.25 \\
\hline Exchangeable $\mathrm{Ca}\left(\mathrm{m}\right.$. Equation $\left.100 \mathrm{~g}^{-1}\right)$ & 3.02 \\
\hline Exchangeable $\mathrm{Mg}\left(\mathrm{m}\right.$. Equation $\left.100 \mathrm{~g}^{-1}\right)$ & 2.14 \\
\hline Available $\mathrm{Si}\left(\mathrm{mg} \mathrm{kg}^{-1}\right)$ & 70.04 \\
\hline Soluble $\mathrm{Al}\left(\mathrm{mg} \mathrm{kg}^{-1}\right)$ & $\mathrm{nd}^{*}$ \\
\hline Exchangeable Al $\left(\mathrm{mg} \mathrm{kg}^{-1}\right)$ & $\mathrm{nd}^{*}$ \\
\hline
\end{tabular}

Table 3. Initial values of soil parameters under the study. ${ }^{\star}$ nd— not detected.

Biochar. Biochars were produced from pyrolysis of Eucalyptus wood, WB (Pointec Pencil Energy Pvt. Ltd., Attibele, Bengaluru) and BB at around $550{ }^{\circ} \mathrm{C}$ (Indo-French Centre, IISc, Bengaluru), while RHB was produced at around $400^{\circ} \mathrm{C}$ by the conventional mound method ${ }^{49}$ in the laboratory of plant mineral nutrition, Soil Science Department, GKVK, Bengaluru. The biochars were finely powdered and sieved using a $0.2 \mathrm{~mm}$ sieve. Biochar samples were combusted at about $950^{\circ} \mathrm{C}$ in CNS analyser for estimation of total contents of $\mathrm{N}$, C, and sulphur (S) (Dry Combustion, CNS, LECO). Acid digested biochar samples were used to quantify the total nutrient content using atomic absorption spectrophotometer (Perkin-Elmer AAnalyst 700 AAS) ${ }^{50}$. Some of the physicochemical properties and nutrient composition of biochars were measured (Table 4).

Identification of phytotoxic levels of aluminium on aerobic rice. A preliminary experiment was conducted to identify the phytotoxic levels of $\mathrm{Al}$ concentration in the soil. The soil was treated with eight levels of $\mathrm{Al}$ concentration $\left(0,500,1,000,2000,6,000,8,000,12,000\right.$ and $\left.16,000 \mathrm{mg} \mathrm{kg}^{-1}\right)$ using aluminium sulphate $\left(\mathrm{Al}_{2}\left(\mathrm{SO}_{4}\right)_{3} \cdot 16 \mathrm{H}_{2} \mathrm{O}\right)$ and incubated for a month maintained at field capacity moisture regime. After one-month, sub samples of $200 \mathrm{~g}$ soil of each was used in separate pots and replicated thrice for growing rice to identify the toxic levels of Al. Further, the comparison between direct seeded and transplanted seedling (10 days old) was done to compare the germination and seedling growth until 15 days. In direct seed method, the rice seedlings could germinate and grow up to two leaf stage under $500 \mathrm{mg} \mathrm{kg}^{-1} \mathrm{Al}$, while no seedlings could survive at more than $1,000 \mathrm{mg} \mathrm{kg}^{-1}$ of $\mathrm{Al}$ in transplanted method. Based on these results, $500 \mathrm{mg} \mathrm{kg}^{-1}$ of Al was selected for inducing $\mathrm{Al}$ toxicity in soil to understand the effect of biochar on decreasing $\mathrm{Al}$ toxicity under incubation study. Further, a pot study with rice plant was conducted with the same level of Al to know the effect of biochar on plant growth under $\mathrm{Al}$ phytotoxicity.

Incubation study. Experimental setup was divided into two conditions based on $\mathrm{Al}$ addition to the soil viz., soil without and with $\mathrm{Al}\left(500 \mathrm{mg} \mathrm{kg}{ }^{-1}\right.$ of $\left.\mathrm{Al}\right)$. Pots (11 and $7 \mathrm{~cm}$ of outer and inner diameter, respectively and $10.5 \mathrm{~cm}$ height) were filled with $200 \mathrm{~g}$ of treated soil with three replications. The soil samples were mixed with three types of biochar viz., BB, WB and RHB at 5, 10 and $20 \mathrm{t} \mathrm{ha}^{-1}$ respectively. The soil without biochar treatment served as control for each experiment. Moisture content was maintained at field capacity by weighing the pots periodically and weight loss due to evaporation was made up by adding distilled water. The treatments were duplicated twice for destructive soil sampling at 15 and at 120 days of incubation. Soil samples were analysed for the $\mathrm{pH}$, soluble and exchangeable $\mathrm{Al}$.

Pot study with rice plants. The pot experiment with rice plants had two sets viz., soil without and with $\mathrm{Al}\left(500 \mathrm{mg} \mathrm{kg}^{-1}\right.$ of Al). These soil samples were mixed with three types of biochar viz., BB, WB and RHB at 10 and $20 \mathrm{t} \mathrm{ha}^{-1}$ respectively. Five kg of treated soil was filled in each pot $(22$ and $14 \mathrm{~cm}$ of outer and inner diameter, respectively and $20 \mathrm{~cm}$ height). Three seeds of aerobic rice, variety Anagha were directly sown in the pot. The moisture level was maintained at field capacity to assure aerobic method of rice cultivation ${ }^{51}$. Nitrogen was applied in 3 splits viz., $50 \%$ as basal, $25 \%$ each at 30 and 60 days after sowing. While $100 \%$ of phosphorus (P) and $\mathrm{K}$ were applied along with basal dose of $\mathrm{N}$. The experiment was carried out till harvest of paddy crop (120 days) in completely randomized design. The soil without biochar treatment served as control for each experiment. Biometric observations such as plant height, shoot dry weight, root dry weight and root length were recorded after the harvest. Soil samples were analysed after the harvest of crop for the $\mathrm{pH}$, EC, exchangeable acidity, exchangeable $\mathrm{Ca}$, available Si along with soluble and exchangeable Al.

Chemical analysis. The soil $\mathrm{pH}$ and EC were measured in a soil-water suspension with 1:2.5 ratio ${ }^{48}$. Soil was treated with $1 \mathrm{~N} \mathrm{KCl}$, shaken for minutes, filtered, and titrated against $0.1 \mathrm{~N} \mathrm{NaOH}$ using phenolphthalein as indicator for measuring exchangeable acidity of soil. Extraction of soil with $1 \mathrm{~N}$ (pH 7) ammonium acetate followed by complexometric titration was followed for exchangeable $\mathrm{Ca}^{52}$. Soil was extracted with $0.5 \mathrm{M}$ acetic acid, the plant available $\mathrm{Si}$ in the extract was determined using UV- visible spectrophotometer at $630 \mathrm{~nm}^{53}$ (Shimadzu Pharma UV $\mathrm{UV}^{-1}, 700 \mathrm{UV}$ visible spectrophotometer).

Soil was treated with $0.02 \mathrm{M} \mathrm{CaCl}_{2}$ in 1:5 ratio for soluble Al estimation. After continuous end to end shaking in a mechanical shaker for $1 \mathrm{~h}$, the solution was centrifuged at 2,500 rpm for $10 \mathrm{~min}$ and then filtered. 


\begin{tabular}{|c|c|c|c|}
\hline & Wood biochar & Bamboo biochar & Rice husk biochar \\
\hline \multicolumn{4}{|l|}{ Physical properties } \\
\hline Bulk density $\left(\mathrm{kg} \mathrm{m}^{-3}\right)$ & 0.31 & 0.61 & 0.53 \\
\hline Particle density $\left(\mathrm{kg} \mathrm{m}^{-3}\right)$ & 1.32 & 1.43 & 1.76 \\
\hline Porosity (\%) & 73.83 & 57.27 & 69.85 \\
\hline Maximum water holding capacity (\%) & 213.31 & 93.71 & 131.41 \\
\hline Colour & 5 YR $2 / 1$ & 5 YR $2 / 1$ & 5 YR $2 / 1$ \\
\hline Ash content (\%) & 8.8 & 6.9 & 39.4 \\
\hline \multicolumn{4}{|l|}{ Chemical properties } \\
\hline $\mathrm{pH}(1: 5)$ & 10.5 & 10.03 & 7.39 \\
\hline Electrical condcutivity $(1: 5)\left(\mathrm{dS} \mathrm{m}^{-1}\right)$ & 4.99 & 1.98 & 1.62 \\
\hline Cation exchange capacity $\left[\mathrm{cmol}\left(\mathrm{p}^{+}\right) \mathrm{kg}^{-1}\right]$ & 26.25 & 23.43 & 38.63 \\
\hline Calcium carbonate equivalent (\%) & 31.00 & 27.50 & 30.50 \\
\hline \multicolumn{4}{|l|}{ Nutrient contents } \\
\hline Carbon (per cent) & 72.5 & 75.5 & 39.33 \\
\hline Nitrogen (per cent) & 0.13 & 0.38 & 0.78 \\
\hline Phosphorus (per cent) & 0.15 & 0.06 & 0.24 \\
\hline Potassium (per cent) & 1.47 & 0.86 & 0.96 \\
\hline Calcium (per cent) & 2.3 & 0.32 & 0.36 \\
\hline Magnesium (per cent) & 0.48 & 0.38 & 0.31 \\
\hline Sulphur (per cent) & 0.07 & 0.1 & 0.05 \\
\hline Sodium (per cent) & 0.1 & 0.03 & 0.05 \\
\hline Silicon (per cent) & 2.03 & 5.22 & 32.5 \\
\hline Zinc $\left(\mathrm{mg} \mathrm{kg}^{-1}\right)$ & 23.9 & 58.6 & 63 \\
\hline Copper $\left(\mathrm{mg} \mathrm{kg}^{-1}\right)$ & 36.6 & 32.7 & 31 \\
\hline Manganese $\left(\mathrm{mg} \mathrm{kg}^{-1}\right)$ & 630.8 & 393.5 & 554 \\
\hline Iron $\left(\mathrm{mg} \mathrm{kg}^{-1}\right)$ & 553.7 & 692.7 & 775.3 \\
\hline Boron $\left(\mathrm{mg} \mathrm{kg}^{-1}\right)$ & 24.42 & 3.44 & 8.36 \\
\hline
\end{tabular}

Table 4. Some of the physico-chemical properties and nutrient contents of biochars under the study.

Sequentially $1 \mathrm{~N} \mathrm{KCl}$ was added to soil in 1:5 ratio for exchangeable Al estimation and after shaking for 30 min, it was centrifuged at 2,500 rpm for $10 \mathrm{~min}$ and filtered. Aluminium in the filtrate was determined by measuring the absorbance at $395 \mathrm{~nm}$ using $\mathrm{UV}$ visible spectrophotometer ${ }^{54}$.

Statistical analysis. The experiment was performed with three replicates. All the data were analysed using one-way ANOVA with SPSS software (IBM Corp. Released 2013. IBM SPSS Statistics for Windows, Version 21.0. Armonk, NY: IBM Corp). Data obtained from the studies were subjected to Tukey's HSD post-hoc test for comparing mean difference between treatments. All the statistical analyses were done at $p \leq 0.05$ level of significance.

Received: 20 August 2019; Accepted: 10 July 2020

Published online: 23 July 2020

\section{References}

1. von Uexküll, H. R. \& Mutert, E. Global extent, development and economic impact of acid soils. Plant Soil 171, 1-15 (1995).

2. Kochian, L. V., Hoekenga, O. A. \& Piñeros, M. A. How do crop plants tolerate acid soils? Mechanisms of aluminum tolerance and phosphorous efficiency. Annu. Rev. Plant Biol. 55, 459-493 (2004).

3. Meena, R. S. et al. Response of alley cropping-grown sesame to lime and sulphur on yield and available nutrient status in an acidic soil of Eastern India. Energ. Ecol. Environ. 4, 65-74 (2019).

4. Kinraide, T. B. Identity of the rhizotoxic aluminium species. Plant Soil 134, 167-178 (1991).

5. Kochian, L. V. Cellular mechanisms of aluminum toxicity and resistance in plants. Annu. Rev. Plant. Physiol. Plant. Mol. Biol. 46, 237-260 (1995).

6. Kopittke, P. M. et al. Identification of the primary lesion of toxic aluminum in plant roots. Plant Physiol. 167, 1402-1411 (2015).

7. Singh, S. et al. Toxicity of aluminium on various levels of plant cells and organism: a review. Environ. Exp. Bot. 137, 177-193 (2017).

8. Lehmann, J., Gaunt, J. \& Rondon, M. Bio-char sequestration in terrestrial ecosystems - a review. Mitig. Adapt. Strat. Glob. Change 11, 403-427 (2006).

9. Van Zwieten, L. et al. Effects of biochar from slow pyrolysis of papermill waste on agronomic performance and soil fertility. Plant Soil 327, 235-246 (2010).

10. Inyang, M. et al. Enhanced lead sorption by biochar derived from anaerobically digested sugarcane bagasse. Sep. Sci. Technol. 46, 1950-1956 (2011).

11. Abdul Halim, N. S. et al. Influence of soil amendments on the growth and yield of rice in acidic soil. Agronomy 8, 165 (2018).

12. Berek, A. K., Hue, N. V., Radovich, T. J. K. \& Ahmad, A. A. Biochars improve nutrient phyto-availability of Hawai'i's highly weathered soils. Agronomy 8, 203 (2018).

13. Lehmann, J. \& Joseph, S. Biochar for Environmental Management: Science and Technology (Earthscan, London, 2009). 
14. Laird, D. A. et al. Impact of biochar amendments on the quality of a typical Midwestern agricultural soil. Geoderma 158, 443-449 (2010).

15. Yuan, J.-H. \& Xu, R.-K. The amelioration effects of low temperature biochar generated from nine crop residues on an acidic Ultisol. Soil Use Manag. 27, 110-115 (2011).

16. Yuan, J.-H., Xu, R.-K., Wang, N. \& Li, J.-Y. Amendment of acid soils with crop residues and biochars. Pedosphere 21, 302-308 (2011).

17. Alburquerque, J. A. et al. Effects of biochars produced from different feedstocks on soil properties and sunflower growth. J. Plant Nutr. Soil Sci. 177, 16-25 (2014).

18. Lin, Q. et al. Assessing the potential of biochar and aged biochar to alleviate aluminum toxicity in an acid soil for achieving cabbage productivity. Ecotoxicol. Environ. Saf. 161, 290-295 (2018).

19. Lehmann, J. et al. Nutrient availability and leaching in an archaeological Anthrosol and a Ferralsol of the Central Amazon basin: fertilizer, manure and charcoal amendments. Plant Soil 249, 343-357 (2003).

20. Gaskin, J. W. et al. Effect of peanut hull and pine chip biochar on soil nutrients, corn nutrient status, and yield. Agron. J. 102, 623-633 (2010).

21. Chintala, R., Mollinedo, J., Schumacher, T. E., Malo, D. D. \& Julson, J. L. Effect of biochar on chemical properties of acidic soil. Arch. Agron. Soil Sci. 60, 393-404 (2014).

22. Qian, L., Chen, B. \& Hu, D. Effective alleviation of aluminum phytotoxicity by manure-derived biochar. Environ. Sci. Technol. 47, $2737-2745(2013)$

23. Major, J., Rondon, M., Molina, D., Riha, S. J. \& Lehmann, J. Maize yield and nutrition during 4 years after biochar application to a Colombian savanna oxisol. Plant Soil 333, 117-128 (2010).

24. Yao, L. et al. Responses of Phaseolus calcaltus to lime and biochar application in an acid soil. PeerJ 7, e6346 (2019).

25. Dai, Z. et al. Potential role of biochars in decreasing soil acidification-a critical review. Sci. Total Environ. 581-582, 601-611 (2017).

26. McBeath, A. V. \& Smernik, R. J. Variation in the degree of aromatic condensation of chars. Org. Geochem. 40, 1161-1168 (2009).

27. Harris, K., Gaskin, J., Cabrera, M., Miller, W. \& Das, K. C. Characterization and mineralization rates of low temperature peanut hull and pine chip biochars. Agronomy 3, 294-312 (2013).

28. Hass, A. et al. Chicken manure biochar as liming and nutrient source for acid appalachian soil. J. Environ. Qual. 41, 1096-1106 (2012).

29. Wan, Q., Yuan, J.-H., Xu, R.-K. \& Li, X.-H. Pyrolysis temperature influences ameliorating effects of biochars on acidic soil. Environ. Sci. Pollut. Res. 21, 2486-2495 (2014).

30. Qian, L., Chen, B. \& Chen, M. Novel alleviation mechanisms of aluminum phytotoxicity via released biosilicon from rice strawderived biochars. Sci. Rep. 6, 29346 (2016).

31. Zhao, R., Coles, N., Kong, Z. \& Wu, J. Effects of aged and fresh biochars on soil acidity under different incubation conditions. Soil Tillage Res. 146, 133-138 (2015).

32. Xiao, X., Chen, B., Chen, Z., Zhu, L. \& Schnoor, J. L. Insight into multiple and multilevel structures of biochars and their potential environmental applications: a critical review. Environ. Sci. Technol. 52, 5027-5047 (2018).

33. Dang, T., Marschner, P., Fitzpatrick, R. \& Mosley, L. M. Assessment of the binding of protons, $\mathrm{Al}$ and Fe to biochar at different $\mathrm{pH}$ values and soluble metal concentrations. Water 10, 55 (2018).

34. Gundale, M. J. \& DeLuca, T. H. Charcoal effects on soil solution chemistry and growth of Koeleria macrantha in the ponderosa pine/Douglas-fir ecosystem. Biol. Fertil. Soils 43, 303-311 (2007).

35. Chan, K. Y., Zwieten, L. V., Meszaros, I., Downie, A. \& Joseph, S. Agronomic values of greenwaste biochar as a soil amendment. Soil Res. 45, 629-634 (2008).

36. Yamato, M., Okimori, Y., Wibowo, I. F., Anshori, S. \& Ogawa, M. Effects of the application of charred bark of Acacia mangium on the yield of maize, cowpea and peanut, and soil chemical properties in South Sumatra Indonesia. Soil Sci. Plant Nutrit. 52, 489-495 (2006).

37. Silber, A., Levkovitch, I. \& Graber, E. R. pH-dependent mineral release and surface properties of cornstraw biochar: agronomic implications. Environ. Sci. Technol. 44, 9318-9323 (2010).

38. Wang, Y., Xiao, X. \& Chen, B. Biochar impacts on soil silicon dissolution kinetics and their interaction mechanisms. Sci. Rep. 8, 8040 (2018).

39. Wang, Y., Xiao, X., Zhang, K. \& Chen, B. Effects of biochar amendment on the soil silicon cycle in a soil-rice ecosystem. Environ. Pollut. 248, 823-833 (2019).

40. Sandhya, K. \& Prakash, N. B. Bioavailability of silicon from different sources and its effect on the yield of rice in acidic, neutral, and alkaline soils of Karnataka, South India. Commun. Soil Sci. Plant Anal. 50, 295-306 (2019).

41. Bakar, R. A. et al. Influence of oil palm empty fruit bunch biochar on floodwater $\mathrm{pH}$ and yield components of rice cultivated on acid sulphate soil under rice intensification practices. Plant Prod. Sci. 18, 491-500 (2015).

42. Sistani, K. R., Savant, N. K. \& Reddy, K. C. Effect of rice hull ash silicon on rice seedling growth. J. Plant Nutr. 20, 195-201 (1997).

43. Korndörfer, G. H. \& Lepsch, I. Chapter 7 Effect of silicon on plant growth and crop yield. In Studies in Plant Science Vol. 8 (eds Datnoff, L. E. et al.) 133-147 (Elsevier, Amsterdam, 2001).

44. Guntzer, F., Keller, C. \& Meunier, J.-D. Benefits of plant silicon for crops: a review. Agron. Sustain. Dev. 32, 201-213 (2012).

45. Corrales, I., Poschenrieder, C. \& Barceló, J. Boron-induced amelioration of aluminium toxicity in a monocot and a dicot species. J. Plant Physiol. 165, 504-513 (2008).

46. Riaz, M. et al. Mechanisms of organic acids and boron induced tolerance of aluminum toxicity: a review. Ecotoxicol. Environ. Saf. $165,25-35(2018)$

47. Zhu, C. Q. et al. Boron reduces cell wall aluminum content in rice (Oryza sativa) roots by decreasing $\mathrm{H} 2 \mathrm{O} 2$ accumulation. Plant Physiol. Biochem. 138, 80-90 (2019).

48. Jackson, M. L. Soil chemical analysis (Prentice Hall of India Pvt. Ltd., New Jersey, 1973).

49. Ogawa, M. \& Okimori, Y. Pioneering works in biochar research Japan. Soil Res. 48, 489-500 (2010).

50. Enders, A. \& Lehmann, J. Comparison of wet-digestion and dry-ashing methods for total elemental analysis of biochar. Commun. Soil Sci. Plant Anal. 43, 1042-1052 (2012).

51. Prakash, N. B., Anitha, M. S. \& Sandhya, K. Behaviour of different levels and grades of diatomite as silicon source in acidic and alkaline soils. Silicon 11, 2393-2401 (2019).

52. Baruah, T. C. \& Barthakur, H. P. A textbook of soil analysis (Vikas Publishing House Pvt. Ltd., Bangalore, 1997).

53. Korndörfer, G. H., Snyder, G. H., Ulloa, M., Powell, G. \& Datnoff, L. E. Calibration of soil and plant silicon analysis for rice production*. J. Plant Nutr. 24, 1071-1084 (2001).

54. Bloom, P. R., Weaver, R. M. \& McBride, M. B. The spectrophotometric and fluorometric determination of aluminum with 8-hydroxyquinoline and butyl acetate extraction. Soil Sci. Soc. Am. J. 42, 713-716 (1978).

\section{Acknowledgements}

This research did not receive any specific grant from funding agencies in the public, commercial, or not-for-profit sectors. The authors offer sincere thanks and appreciation to Indo-French Centre, Indian Institute of Science 
(IISc), Bengaluru for providing bamboo biochar and Pointec Private Limited, Bengaluru, for providing wood biochar for the study.

\section{Author contributions}

R.S. and N.B.P. conceived and designed the experiment, R.S. performed the sampling, cultivation, and lab analyses. R.S. carried out the data analysis and wrote the first draft. N.B.P revised and provided comments on the manuscript.

\section{Competing interests}

The authors declare no competing interests.

\section{Additional information}

Correspondence and requests for materials should be addressed to R.S.

Reprints and permissions information is available at www.nature.com/reprints.

Publisher's note Springer Nature remains neutral with regard to jurisdictional claims in published maps and institutional affiliations.

(c) Open Access This article is licensed under a Creative Commons Attribution 4.0 International License, which permits use, sharing, adaptation, distribution and reproduction in any medium or format, as long as you give appropriate credit to the original author(s) and the source, provide a link to the Creative Commons license, and indicate if changes were made. The images or other third party material in this article are included in the article's Creative Commons license, unless indicated otherwise in a credit line to the material. If material is not included in the article's Creative Commons license and your intended use is not permitted by statutory regulation or exceeds the permitted use, you will need to obtain permission directly from the copyright holder. To view a copy of this license, visit http://creativecommons.org/licenses/by/4.0/.

(c) The Author(s) 2020 